\title{
Inspraak in de rechtspraak; de rol van derden in de procedure
}

\author{
Verslag van de voorjaarsvergadering 2018 van \\ de Nederlandse Vereniging voor Procesrecht
}

\author{
Jacobus Dammingh en Marijn vanden Berg*
}

\begin{abstract}
Algemeen
De voorjaarsvergadering van 2018 van de Nederlandse Vereniging voor Procesrecht (NVvP), die plaatsvond op 15 juni 2018, droeg de titel 'Inspraak in de rechtspraak; de rol van derden in de procedure'.

De voorzitter, prof. mr. C.J.M. Klaassen, heeft bij wijze van inleiding (de keuze voor) het thema van deze vergadering en de achtergronden ervan toegelicht. Als uitgangspunt geldt dat uitsluitend de partijen in een procedure aan de uitkomst daarvan zijn gebonden, waardoor de uitspraak van de rechter ook alleen tussen de procespartijen ten uitvoer kan worden gelegd. Soms werken rechterlijke uitspraken echter ook ten voordele of ten nadele van anderen (dan de procederende partijen). Zo kan de uitspraak in een procedure tussen de koper van een nieuwbouwwoning en de verkoper over een (vermeende) ondeugdelijke constructie van die woning een belangrijke rol spelen in het (processuele) debat tussen de verkoper en de architect over diens rol in dit verband. En de uitkomst van een procedure over de eigendom van een stuk grond (tussen vermeende eigenaren) kan mede van betekenis zijn voor de positie van de erfpachter van die grond. In deze voorbeelden gaat het om derden die in een (meer of minder) directe relatie tot een van de procespartijen staan. Ten aanzien van deze derden kent het Wetboek van Burgerlijke Rechtsvordering (Rv) de vrijwaring (ex art. 210) en de voeging (vergelijk art. 217). Daarnaast kent het $\mathrm{Rv}$ de tussenkomst door een derde (vergelijk art. 217), aan de orde in het geval dat de derde het verlies (of de benadeling) van een hem toekomend recht wil voorkomen. ${ }^{1}$ Voor de verzoekprocedure geldt meer in het algemeen dat iedere belanghebbende zich daarin mag mengen.

Maar er kunnen ook derden zijn die niet in een directe relatie tot de procespartijen staan (waardoor vrijwaring, voeging of tussenkomst niet aan de orde is), maar voor wie de uitspraak in een procedure wel gevolgen kan hebben. We kennen in Nederland geen precedentwerking. Dit neemt niet weg
\end{abstract}

Mr. J.J. Dammingh is universitair hoofddocent burgerlijk (proces)recht aan de Radboud Universiteit Nijmegen. Mr. L.M. van den Berg is stafjurist in de Rechtbank Gelderland.

1. Zie hierover o.m. H.J. Snijders, C.J.M. Klaassen \& G.J. Meijer, Nederlands burgerlijk procesrecht, Deventer: Wolters Kluwer 2017, nr. 183. dat de rechtspraak van met name de Hoge Raad en de Afdeling bestuursrechtspraak van de Raad van State (hierna: $\mathrm{ABRvS}$ ) een rechtsvormend effect heeft, in die zin dat deze richtinggevend is voor de rechterlijke beoordeling in andere (min of meer) vergelijkbare gevallen. In de civiele cassatierechtspraak heeft vooral voormalig A-G Spier de aandacht op dat rechtsvormende effect gevestigd (in procedures over onder meer de bancaire aansprakelijkheid en de aansprakelijkheid in geval van beroepsziekten). Spier heeft zich in zijn conclusies geregeld afgevraagd waar de door de Hoge Raad te nemen beslissing meer in het algemeen toe zou (moeten) leiden. Ofwel: wat betekent die beslissing voor andere betrokkenen (vergelijkbare 'slachtoffers'), die niet over de kwestie zijn gehoord, maar wel de gevolgen van die beslissing ondervinden? Dit speelt eveneens bij massaclaims en de met het oog daarop - en vergelijkbare procedures - geïntroduceerde regeling van de prejudiciële vragen aan de Hoge Raad (zoals vervat in art. 392-394 Rv). Met het antwoord van de Hoge Raad op een aan hem voorgelegde prejudiciële vraag wordt immers beoogd om richting te geven aan andere procedures waarin dezelfde vraag speelt.

Een van de onderwerpen tijdens deze vergadering zal zijn met welke invalshoeken de Hoge Raad in dit verband rekening dient te houden. Welke mogelijkheden zijn er voor anderen dan partijen om in een procedure (als derden) hun stem te laten horen? Zo volgt uit art. 393 lid 2 Rv dat de Hoge Raad - in het kader van een aan hem voorgelegde prejudiciële vraag - 'kan' bepalen dat ook anderen dan partijen gelegenheid krijgen om schriftelijke opmerkingen te maken. In welke gevallen is dat mogelijk c.q. wenselijk?

De directe aanleiding voor het onderwerp van deze vergadering is dat de $A B R v S$ in het najaar van 2017 - voor het eerst gebruik heeft gemakkt van de figuur van de 'amicus curiae' ('vriend van de rechter'). In dat geval wordt aan derden verzocht om hun visie te geven c.q. inlichtingen te verstrekken met het oog op een door de rechter (in een concrete zaak) te geven beslissing. Er is (nog) geen wettelijke basis voor de inzet van het instrument van de amicus curiae. Wel bepaalt art. 8:45 
lid 1 van de Algemene wet bestuursrecht (Awb) dat de bestuursrechter partijen en anderen kan verzoeken om binnen een door hem te bepalen termijn schriftelijk inlichtingen te geven. Omdat die inlichtingen dus ook aan 'anderen' kunnen worden gevraagd, heeft de $\mathrm{ABRvS}$ op de voet van art. 8:45 lid 1 Awb van de amicus curiae gebruik gemaakt.

Het inzetten van 'amici' door de rechter roept vragen op. Welke invloed mogen c.q. moeten de procespartijen daarop uitoefenen? Welke derden mogen als amici worden geraadpleegd? Ziet hun inbreng alleen op juridische vragen, of kan die inbreng ook op feitelijke kwesties betrekking hebben? Moet (c.q. mag) de inbreng van amici openbaar toegankelijk zijn? Wat zijn de gevolgen van de inbreng van amici voor partijen? En in hoeverre is het wenselijk dat de rechter (mede) met het oog op de waarheidsvinding - die (inmiddels) ook in het civiele proces een prominente rol vervult - derden in de procedure kan betrekken?

Hierover peinzend rezen binnen het bestuur van de NVvP meer vragen (in breder verband), zowel over de mogelijkheden voor de rechter en partijen om derden in een procedure te betrekken als over de mogelijkheden van derden om zich (desgewenst) in een procedure te mengen. In hoeverre biedt bijvoorbeeld art. $118 \mathrm{Rv}$ (= art. 30g Rv-nieuw) een 'kapstok' voor partijen om derden in een procedure te betrekken? De Hoge Raad heeft zich hierover weliswaar al herhaaldelijk uitgelaten, maar het toepassingsbereik van art. $118 \mathrm{Rv}$ blijkt in de praktijk toch (nog) geregeld vragen op te roepen en tot uiteenlopende oordelen in de lagere rechtspraak te leiden. ${ }^{2}$ Vandaar de keuze voor 'Inspraak in de rechtspraak; de rol van derden in de procedure' als onderwerp van deze vergadering.

De voorzitter rondt haar inleiding af met een korte introductie van de sprekers. Prof. mr. dr. J.C.A. de Poorter zal ingaan op de inzet van de amicus curiae door de bestuursrechter. Prof. dr. mr. E. Bauw zal de inspraak van derden in het civiele geding in het algemeen bespreken, terwijl prof. dr. J.S. Kortmann met name aandacht aan de vrijwaring en de litis denuntiatio (in een civiele procedure) zal besteden.

\section{Stellingen:}

\section{Inleiding prof. mr. dr. J.C.A. de Poorter ${ }^{3}$}

1. Ook de hoogste algemene bestuursrechter heeft een rechtsvormende taak, dus moeten hem instrumenten worden geboden om beter zicht te krijgen op de gevolgen die zijn beslissingen hebben voor de samenleving.

2. Als de amicus curiae wordt ingezet, dient dit te gebeuren door een openbare consultatie.

3. De door de amici verstrekte schriftelijke inlichtingen behoren na binnenkomst integraal openbaar te worden gemaakt door publicatie op de website van het rechterlijk college.

2. Zie hierover o.m. J.A. Möhlmann, 'Herstel van verzuim en strijd tegen tegenstrijdige beslissingen. Over de oproeping van derden ex art. 118 Rv', TCR 2017, afl. 3, p. 100-110.

3. Hoogleraar Bestuursrecht aan de Tilburg University.
4. De vraag of en waarover de amici om schriftelijke inlichtingen wordt gevraagd is een bevoegdheid van de rechter; procespartijen behoren op dit punt geen inspraak te hebben.

5. De rechter moet een amicus curiae op de zitting kunnen bevragen.

6. Behoefte aan een wettelijke regeling van de amicus curiae in het bestuursrecht?

a. In de Algemene wet bestuursrecht behoeft geen bevoegdheid te worden opgenomen voor de hoogste bestuursrechter om de amicus curiae in te zetten.

b. In de Algemene wet bestuursrecht dient voor de hoogste bestuursrechter de bevoegdheid te worden opgenomen om de amicus curiae in te zetten.

c. In de Algemene wet bestuursrecht behoeft geen bevoegdheid te worden opgenomen voor de hoogste bestuursrechter om de amicus curiae in te zetten, maar de amicus curiae verdient wel uitwerking in een procesreglement.

d. In de Algemene wet bestuursrecht dient voor de hoogste bestuursrechter een algemeen geformuleerde bevoegdheid te worden opgenomen om de amicus curiae in te zetten, die in een procesreglement nader wordt uitgewerkt.

\section{Inleiding}

De Poorter is - samen met zijn Tilburgse collega's Van Heusden en De Lange - bezig met een onderzoek naar de eerste ervaringen met de amicus curiae in de praktijk van de ABRvS. ${ }^{4}$ Hij zal nader ingaan op de resultaten van dit onderzoek. Hierbij past wel de kanttekening dat slechts de eerste bevindingen kunnen worden gepresenteerd omdat het onderzoek nog niet is afgerond.

De ABRvS heeft tot nu toe in (slechts) drie zaken gebruik gemaakt van het instrument van de amicus curiae. ${ }^{5}$ De onderzoekers hebben gesproken met de rechters, de partijen en de amici in deze zaken en zij mochten ook de procesdossiers inzien. Tevens hebben zij aan de betrokkenen questionnaires voorgelegd.

In het onderzoek van De Poorter c.s. staan de volgende vragen centraal:

1. Beantwoordt de inzet van de amicus curiae aan het doel dat de ABRvS daarmee voor ogen had (en in hoeverre

4. J.C.A. de Poorter, L.A. van Heusden \& C.J. de Lange, De amicus curiae geëvalueerd. Over de eerste indrukken van de inzet van het instrument van de amicus curiae in procedures voor de Afdeling bestuursrechtspraak, Den Haag: Raad van State 2018.

5. Zie over de amicus curiae o.m. J.C.A. de Poorter, 'Het belang van de amicus curiae voor de rechtsvormende taak van de hoogste bestuursrechters. Naar een regeling van de amicus curiae in de Algemene wet bestuursrecht', NTB 2015, afl. 7, p. 40-49, J.C.A. de Poorter, 'Responsief bestuursrecht en de amicus curiae', NTB 2018/34, p. 201-203 en T. Barkhuysen, 'Betere bestuursrechtelijke rechtsvorming met een amicus curiae?', NJB 2014, afl. 10, p. 633. 
hebben zich de vooraf gevreesde negatieve bijwerkingen geopenbaard)?

2. Op welke wijze is de amicus curiae ingebed in de procedure voor de ABRvS?

Wat is het doel van de inzet van de amicus curiae? Kort gezegd is dat het vergroten van de kwaliteit van het proces van rechtsvorming door middel van het vergaren van informatie over de macrogevolgen die een (rechtsvormende) uitspraak van de ABRvS zal (kunnen) hebben. Daarnaast draagt de inzet van de amicus curiae - door participatie, representatie en transparantie - bij aan de legitimiteit van de uitspraak. De amicus curiae is voor de rechter een instrument dat vergelijkbaar is met een internetconsultatie met het oog op (tot stand te brengen) wetgeving. Door middel van een internetconsultatie kunnen burgers, bedrijven en maatschappelijke organisaties kennisnemen van het concept voor een wetsvoorstel en hun mening daarover geven. Met de amicus curiae wordt in zekere zin hetzelfde nagestreefd, maar dan met het oog op de rechtsvorming door de rechter.

\section{De drie zaken}

Zoals gezegd is tot nu toe in slechts drie zaken van de amicus curiae gebruik gemaakt. De eerste zaak had betrekking op (een bestemmingsplan en een omgevingsvergunning voor) het veranderen van een tankstation met LPG-installatie in Purmerend. Aan de orde was de vraag of de in de Regeling externe veiligheid inrichtingen (Revi) vervatte afstanden wel in overeenstemming zijn met hoger recht. In deze zaak is aan de staatssecretaris van Infrastructuur en Milieu gevraagd om - als amicus - inlichtingen te verstrekken. De ABRvS heeft nog geen uitspraak in deze zaak gedaan.

De tweede zaak ging over een waarschuwing van de minister van Sociale Zaken en Werkgelegenheid op grond van art. 28a van de Arbeidsomstandighedenwet (Arbowet). Moest die waarschuwing als een 'besluit' in de zin van art. 1:3 Awb worden aangemerkt? Aan de A-G is verzocht om een conclusie te nemen. De vragen die in dit verband aan de A-G zijn voorgelegd, zijn ook op de website van de Raad van State geplaatst met de (openbare) uitnodiging aan eenieder om daarop te reageren. In totaal zijn 25 reacties (door de ABRvS) ontvangen. De A-G heeft, met inachtneming van deze reacties, op 24 januari 2018 een conclusie genomen, en de ABRvS heeft op 2 mei 2018 uitspraak gedaan. ${ }^{6}$

De derde zaak betrof de herziening van een exploitatieplan in de gemeente Barneveld. De ABRvS heeft aan een zestal instanties verzocht inlichtingen te verstrekken over de vraag hoe de gemeente de kosten voor grondverwerving van een zogenoemde 'bovenwijkse voorziening' in het exploitatieplan mocht opnemen. Mochten die kosten op een taxatierapport worden gebaseerd ('taxatiebenadering') of moest van de werkelijke kosten worden uitgegaan ('werkelijke kostenbenadering')? Het antwoord op deze vraag was niet direct uit de tekst van de wet (of de toelichting daarop) af te leiden. De ABRvS

6. Zie ECLI:NL:RVS:2018:249 voor de conclusie van de A-G en ECLI:NL:RVS:2018:1449 voor de uitspraak van de ABRvS. heeft daarom besloten zes instanties gericht uit te nodigen om - als amici - inlichtingen te verstrekken. ${ }^{7}$ De ABRvS heeft op 16 maart 2018 uitspraak gedaan en de ontvangen inlichtingen zijn daarin verwerkt. ${ }^{8}$

\section{Heeft het gewerkt?}

Heeft de inzet van de amicus curiae in de voormelde drie zaken het beoogde effect gesorteerd? Die vraag is niet (zo) makkelijk te beantwoorden. Volgens De Poorter is de reden om van de amicus curiae gebruik te maken in elk van die zaken een andere geweest. In de 'waarschuwingszaak' lijkt de ABRvS vooral op zoek te zijn geweest naar informatie over wat haar beslissing over de waarschuwing ex art. 28a Arbowet zou kunnen betekenen voor min of meer vergelijkbare gevallen (andere soorten waarschuwingen en op een waarschuwing lijkende rechtsfiguren). Hier is met de inzet van de amicus curiae dus getracht om zicht te krijgen op de juridische context van het probleem (de 'judicial consequences'). In de zaak over de herziening van het exploitatieplan lijkt de ABRvS vooral informatie te hebben willen vergaren over de buiten het recht gelegen gevolgen van de door haar te nemen beslissing (de 'behavioural consequences'). ${ }^{9}$ En in de zaak over het tankstation in Purmerend lijkt de reden voor de inzet van de amicus curiae weer een andere te zijn geweest. Aan de staatssecretaris is gevraagd om inlichtingen te verstrekken over een door hemzelf ontworpen regeling (de Revi). De Poorter betwijfelt overigens of hier wel van een amicus curiae kan worden gesproken. De staatssecretaris trad zijns inziens veeleer als 'pseudoverweerder' op. Zijn positie was een andere dan die van een amicus: hij was immers op de zitting aanwezig en mocht daar ook het woord voeren. Over de 'doorwerking' van de door de staatssecretaris verstrekte informatie in de (uiteindelijke) beslissing valt weinig te zeggen omdat de ABRvS nog geen uitspraak in deze zaak heeft gedaan.

Hebben de verstrekte inlichtingen in de andere twee zaken - de waarschuwingszaak en de zaak over het exploitatieplan daadwerkelijk aan de rechtsvorming door de ABRvS bijgedragen? Volgens De Poorter lijkt dat inderdaad het geval te zijn. In de zaak over het exploitatieplan zijn de ontvangen inlichtingen in de uitspraak weergegeven en de ABRvS is bij de onderbouwing van haar beslissing ook ingegaan op de diverse standpunten van de amici. ${ }^{10}$ In de interviews met hen hebben de betrokken rechters aangegeven dat de inbreng van de amici waardevol is geweest.

In de waarschuwingszaak is minder goed vast te stellen wat de waarde van de inlichtingen van de amici is geweest. In de

7. De volgende zes instanties zijn (gericht) uitgenodigd: de minister van Binnenlandse Zaken en Koninkrijksrelaties, de Vereniging van Nederlandse Gemeenten (VNG), het Interprovinciaal Overleg (IPO), de Vereniging van Nederlandse Projectontwikkeling Maatschappijen (NEPROM), het Instituut voor Bouwrecht (IBR) en de NVB Vereniging voor ontwikkelaars \& bouwondernemers (NVB).

8. ECLI:NL:RVS:2018:903.

9. Zie hierover ook De Poorter 2015 en De Poorter 2018.

10. Zie o.m. r.o. 9, 10 en 11 van de uitspraak d.d. 16 maart 2018 (ECLI:NL:RVS:2018:903). 
uitspraak van de ABRvS wordt niets over de verkregen inlichtingen gezegd. Dit terwijl de A-G in zijn conclusie wel aandacht aan de van de amici ontvangen informatie heeft besteed. De interviews geven een wisselend beeld: één staatsraad was weinig enthousiast over de inzet van de amicus curiae, maar de twee andere staatsraden (in deze zaak) waren aanmerkelijk positiever. Uit (de resultaten van) de questionnaires blijkt dat de partijen in zowel de waarschuwingszaak als de zaak over het exploitatieplan achter de inzet van de amicus curiae stonden: zij gaven aan het (volledig) eens te zijn met de stelling dat het goed is dat in hun zaak van de amicus curiae gebruik is gemaakt.

\section{Waren er negatieve bijwerkingen?}

In de literatuur is als negatieve bijwerking van de inzet van de amicus curiae genoemd dat de rechter wordt blootgesteld aan belangenbehartiging door anderen dan de procederende partijen ('lobbyisme in de rechtszaal'). De Poorter meent dat het risico van belangenbehartiging - voor zover daarvan al sprake zou zijn - kan worden tegengegaan door (a) de reacties van de amici openbaar te maken (op de website van het rechterlijk college) en (b) een evenwichtige representatie van belangen na te streven.

De - voorzichtige - conclusie die De Poorter trekt uit de ervaringen met de inzet van de amicus curiae in de voormelde drie zaken is dat er reden voor optimisme is. Met name in de zaak over het exploitatieplan heeft de inzet van de amicus meerwaarde gehad. De vooraf gevreesde (negatieve) bijwerkingen, zoals een stortvloed aan nutteloze reacties of een al te eenzijdige belangenbehartiging, hebben zich niet voorgedaan.

De Poorter meent wel dat met het oog op de 'processuele inbedding' van de amicus curiae in ieder geval nog naar de volgende aspecten moet worden gekeken:

\section{a. Het uitnodigingenbeleid}

In de voormelde drie zaken is met verschillende wijzen van uitnodigen (van de amici) geëxperimenteerd: in de waarschuwingszaak is voor een openbare consultatie gekozen, terwijl in de andere twee zaken amici gericht zijn uitgenodigd. Welke aspecten zijn van belang met het oog op de keuze voor gericht of openbaar uitnodigen? Uit de interviews is gebleken dat sommige rechters een voorkeur hebben voor het gericht uitnodigen van amici. Dat is te begrijpen in zaken waarin de aan de orde zijnde macrobelangen duidelijk zijn te identificeren, waardoor voor elk van die belangen de juiste representant kan worden uitgenodigd. Wanneer de rechter daarentegen wil worden voorgelicht over wat zijn beslissing in een zaak kan betekenen voor andere, min of meer vergelijkbare gevallen, dan ligt een open consultatie vermoedelijk meer voor de hand.

Maar niet iedereen staat achter het 'tweesporenbeleid' (van openbaar en gericht uitnodigen). Uit de interviews bleek dat sommige rechters vinden dat in het licht van transparantie en participatie (het betrekken van de samenleving bij de rechtsvorming) een openbare uitnodiging de regel behoort te zijn. Deze benadering spreekt ook De Poorter aan, maar zij hoeft er wat hem betreft niet aan in de weg te staan dat (zo nodig) daarnaast één of enkele (rechts)personen gericht worden uitgenodigd. In een concreet geval kan dat vanuit het oogpunt van representativiteit wenselijk zijn.

\section{b. Openbaarheid van de ontvangen reacties}

Het experimenteren met de inzet van de amicus curiae is met enkele kinderziekten gepaard gegaan. Eén daarvan was de openbaarheid van de verstrekte inlichtingen. Zo is in de waarschuwingszaak niet met de amici gecommuniceerd over de openbaarheid van de door hen verstrekte inlichtingen. In de zaak over het exploitatieplan is pas in een later stadium aan de amici gevraagd of zij ermee akkoord gingen dat de ABRvS de door hen verstrekte informatie in haar uitspraak zou verwerken.

Volgens De Poorter is het wenselijk dat op dit punt een uniforme praktijk ontstaat. Het verdient wat hem betreft aanbeveling dat (voortaan) in de uitnodiging aan de amici wordt vermeld dat zij met het verstrekken van inlichtingen ook toestemming aan de ABRvS geven om hun inlichtingen expliciet - en herleidbaar tot de amicus - in de uitspraak te verwerken. Het zou slechts bij hoge uitzondering moeten worden toegestaan om anoniem inlichtingen te verstrekken (hier zou wellicht de 'art. 8:29 Awb-praktijk' over geheimhouding van stukken - naar analogie - kunnen worden toegepast). De Poorter zou voor zover het de openbaarmaking betreft nog wel een stap verder willen gaan door elke van een amicus ontvangen reactie (integraal) op de website van de ABRvS te plaatsen. Dat zou bijdragen aan de transparantie - de samenleving moet kunnen nagaan welke inlichtingen door de amici aan de rechter zijn verstrekt - en heeft mogelijk als bijkomend voordeel dat een (extra) drempel voor (te) eenzijdige belangenbehartiging (door amici) wordt opgeworpen.

\section{c. De amicus ten opzichte van partijen en andere amici}

Eenduidigheid ontbrak ook in de voormelde drie zaken voor zover het de rol van de amici in relatie tot de procespartijen betrof. In de zaak over het tankstation in Purmerend heeft de ABRvS partijen niet betrokken bij de inzet van de staatssecretaris als 'amicus'. Ook zijn partijen niet in de gelegenheid gesteld om te reageren op de verkregen inlichtingen. In de waarschuwingszaak hebben partijen geen gelegenheid gekregen om schriftelijk op de ontvangen inlichtingen te reageren. Zij mochten echter wel ter zitting een reactie op de inlichtingen van de amici geven. In de zaak over het exploitatieplan mochten partijen wél vooraf hun standpunt over de inschakeling van amici kenbaar maken. Ook kregen zij gelegenheid om zich uit te laten over de vragen die aan de amici zouden worden gesteld en de uit te nodigen amici, en zij hebben eveneens mogen reageren op de verstrekte inlichtingen. De geraadpleegde amici in deze zaak hebben wel onderling kennis kunnen nemen van de aan de $\mathrm{ABRvS}$ verstrekte inlichtingen, maar zij hebben niet op elkaars inbreng mogen reageren.

Het is De Poorter niet bekend waarom de ABRvS in elk van de drie zaken een andere werkwijze heeft gevolgd. De meest logische verklaring is dat de $\mathrm{ABRvS}$ nog haar weg hierin 
moet vinden. Wat De Poorter betreft is het wenselijk dat ook op dit punt uniformiteit wordt nagestreefd. Naar zijn mening dienen partijen in de gelegenheid te worden gesteld om te reageren op het voornemen om een amicus curiae in te schakelen. Hoewel het aan de rechter is om al dan niet van de amicus curiae gebruik te maken, is het van belang om partijen vooraf over de vraagstelling en de wijze van uitnodigen te horen, alsmede - indien voor een gerichte uitnodiging wordt gekozen over de personen c.q. instanties die zullen worden uitgenodigd. De Poorter is van mening dat partijen in de gelegenheid behoren te worden gesteld om schriftelijk te reageren op de door de amici verstrekte inlichtingen. Hij vindt het niet nodig dat de amici op elkaar kunnen reageren of op wat partijen naar aanleiding van de ontvangen inlichtingen naar voren hebben gebracht. Het verdient wat hem betreft wel aanbeveling dat de rechter de bevoegdheid krijgt om een amicus op de zitting te horen.

\section{Naar een wettelijke regeling?}

Dient in de Awb een (expliciete) regeling ter zake van de amicus curiae te worden opgenomen? Wat De Poorter betreft zou in ieder geval de bevoegdheid voor de hoogste bestuursrechter om de amicus curiae in te zetten op termijn in de Awb moeten worden verankerd. $\mathrm{Nu}$ schakelt de ABRvS de amicus op de voet van art. 8:45 Awb in, maar daar is die bepaling eigenlijk niet voor bedoeld. Een sobere wettelijke regeling lijkt hem voldoende. Bij een expertmeeting is betoogd dat met een dergelijke (sobere) wettelijke regeling wordt benadrukt dat de amicus curiae als instrument uitsluitend aan de hoogste bestuursrechter ter beschikking staat. Bovendien draagt een wettelijke regeling bij aan de legitimiteit van de inzet van het instrument. De Poorter onderschrijft dit betoog.

De Poorter sluit af met de opmerking dat het onderzoek van hem en zijn collega's vooralsnog geen aanleiding geeft om niet verder te gaan met het experiment van de amicus curiae. De ABRvS moet de ruimte krijgen om (in de nabije toekomst) meer ervaring op te doen met het gebruik van dit instrument. De aldus te ontwikkelen 'best practices' zouden te zijner tijd eventueel in een procesreglement kunnen worden vervat, maar voorshands zou De Poorter de speelruimte voor de ABRvS om best practices te ontwikkelen niet willen beperken.

\section{Discussie}

Kastein (advocaat) legt drie vragen aan De Poorter voor. Ten eerste vraagt hij zich af waarom de staatssecretaris in de 'Revikwestie' niet als derde-belanghebbende in de procedure is betrokken. In de Awb is de figuur van de derde-belanghebbende immers al geregeld. Waarom is gekozen voor een inzet als amicus curiae?

De Poorter meent dat een inschakeling van de staatssecretaris als derde-belanghebbende niet mogelijk was. Art. 8:26 Awb is namelijk bedoeld voor een derde-belanghebbende die zelf een (direct) belang bij het bestreden besluit heeft, en dat was niet aan de orde. Overigens merkt De Poorter op dat de staatssecretaris wel belang had bij de uitkomst van het geschil.
Je kunt je afvragen of er wellicht behoefte is aan een aparte regeling die erin voorziet dat een bestuursorgaan dat belang heeft bij de uitkomst van een geschil, door de rechter kan worden gehoord.

De tweede vraag van Kastein heeft betrekking op het uitnodigen - door de rechter - van een amicus curiae. In hoeverre kan aansluiting worden gezocht bij de (al bestaande) wettelijke regeling aangaande het inschakelen van een deskundige? Een deskundige wordt niet alleen op deskundigheid geselecteerd, maar ook op onpartijdigheid (terwijl die onpartijdigheid bij de amicus curiae ter discussie kan staan).

Volgens De Poorter kunnen we - voor zover het de inzet van de amicus curiae betreft - zeker iets leren van de wijze waarop het inschakelen van een deskundige is geregeld (in art. 8:47 Awb).

De derde vraag van Kastein is of het wel wenselijk is om een uniforme werkwijze na te streven bij de inzet van een amicus curiae. Moet die werkwijze niet juist specifiek op (de bijzonderheden van) de betreffende zaak worden afgestemd? En ligt het niet voor de hand om eerst een regiezitting te houden alvorens tot de inzet van een amicus curiae over te gaan?

In antwoord op deze vraag merkt De Poorter op dat de selectie van amici (door de rechter) 'kwetsbaar' is (het kan ertoe leiden dat de rechterlijke onpartijdigheid in twijfel wordt getrokken). Om die reden pleit hij ook voor (zo veel mogelijk) transparantie en openbaarheid. Hoewel er ruimte moet zijn om in een concrete zaak 'maatwerk' te leveren voor zover het de selectie en de inzet van een amicus curiae betreft, verdient het naar de mening van De Poorter aanbeveling dat in zekere mate een uniforme praktijk ontstaat (met betrekking tot het uitnodigen en de inzet van een amicus curiae).

Van der Grinten (wetgevingsjurist) beaamt dat de selectie van amici 'kwetsbaar' is. De onpartijdigheid van de rechter kan ter discussie komen te staan, zodra hij bepaalde personen gericht als amici gaat uitnodigen.

In reactie hierop benadrukt De Poorter dat openbaar uitnodigen daarom de voorkeur verdient, hoewel er situaties kunnen zijn waarin het wenselijk is dat - naast de openbare uitnodiging - ook één of enkele amici gericht worden uitgenodigd. Zo zou hij zich kunnen voorstellen dat het in een civielrechtelijk geding nuttig kan zijn wanneer bijvoorbeeld de Consumentenbond zijn visie geeft.

Hermans (advocaat) onderstreept met een voorbeeld uit het Amerikaanse recht dat het openbaar uitnodigen zonder meer de voorkeur verdient. De Poorter is het daarmee eens, maar plaatst wel de kanttekening dat de keerzijde van openbaar uitnodigen is dat je niet weet welke personen c.q. instanties - als amici - van zich zullen laten horen (en in beginsel zal toch met alle ontvangen inlichtingen 'iets' moeten worden gedaan). 
Stellingen:

\section{Inleiding prof. dr. mr. E. Bauw ${ }^{11}$}

1. De mogelijkheid van procederen over collectieve belangen bij de civiele rechter (public interest litigation, PIL) vormt in de huidige tijd een vitaal onderdeel van de democratische rechtsstaat.

2. Ook in feitelijke instantie bestaat in (civiele) procedures over collectieve belangen behoefte aan de mogelijkheid voor de rechter om anderen dan partijen in staat te stellen inbreng te leveren.

3. De rechter moet een amicus curiae op zitting kunnen bevragen.

\section{Inleiding}

In zijn inleiding over de inspraak van derden in een civiele procedure onderscheidt Bauw de volgende drie situaties:

1. de mogelijkheden voor derden om in een procedure (waarin zij geen partij zijn) hun belang aan de rechter kenbaar te maken en daarvoor op te komen;

2. de mogelijkheden voor de rechter om te worden geïnformeerd door derden over de (mogelijke) gevolgen van een door hem te nemen beslissing;

3. inspraak (van derden) in de organisatie van de rechtspraak.

\section{Ad 1. De mogelijkheden voor derden om in een procedure voor hun belang op te komen}

In het klassieke 'tweepartijenmodel' is er nauwelijks ruimte voor inspraak van derden. Dit model kenmerkt zich door partijautonomie en dominus litis ('it's my party'). Inspraak van derden in de procedure past daar niet bij. Slechts onder strikte voorwaarden wordt de betrokkenheid van derden in de procedure (door Rv) toegestaan. Bauw onderscheidt in dit verband de vrijwillige interventie door een derde en de gedwongen deelname van een derde aan de procedure.

Van vrijwillige interventie door een derde is sprake bij voeging en bij tussenkomst (zie art. $217 \mathrm{Rv}$ ). Van voeging is sprake wanneer een derde zich aan de zijde van een van de partijen in de procedure schaart. De derde beoogt dan (niet méér dan) dat de vordering - in de hoofdzaak - wordt toegewezen (bij voeging aan de zijde van de eiser) dan wel wordt afgewezen (bij voeging aan de zijde van de gedaagde/verweerder). ${ }^{12}$

Bij tussenkomst stelt de derde een eigen vordering in, die zich tegen de beide partijen in de procedure richt. Hierdoor kan met zijn (eigen) belang rekening worden gehouden. ${ }^{13}$

Vóór voeging en tussenkomst pleiten dat dubbele bewijsverrichtingen en het risico van tegenstrijdige uitspraken kunnen

11. Hoogleraar Privaatrecht en rechtspleging aan de Universiteit Utrecht en hoogleraar Rechtspleging aan de Universiteit van Amsterdam.

12. Voorbeeld: de derde voegt zich aan de zijde van de gedaagde omdat de gedaagde een regresrecht jegens hem heeft.

13. Voorbeeld: een registergoed is twee keer verkocht. De tweede koper vordert in een procedure levering van het (ook) aan hem verkochte goed. De eerste koper kan dan in het geding tussenkomen en - na toelating in de procedure - (van de verkoper) levering van het verkochte goed aan hem vorderen. worden vermeden (doordat geen afzonderlijke procedures hoeven te worden gevoerd). Dit bevordert de efficiency en de kwaliteit van de rechtspraak. Een niet onbelangrijk nadeel is echter dat de procedure vaak wordt vertraagd en ook gecompliceerder wordt. De Hoge Raad is restrictief voor zover het de toelating van een derde in een procedure via voeging of tussenkomst betreft.

Gedwongen deelname van een derde aan een procedure is onder meer bij vrijwaring als bedoeld in art. 210 e.v. Rv aan de orde.

De conclusie van Bauw is voorshands dat in de 'klassieke' procedure niet of nauwelijks een rol voor derden is weggelegd. Het klassieke model is in de loop der jaren echter onder druk komen te staan door de toegenomen complexiteit van de samenleving, de talrijke economische en technologische ontwikkelingen, de toegenomen mondigheid van de burgers en de gewijzigde rol van de rechter als gevolg van de doorwerking van het Europese recht in de nationale rechtsorde.

Gebleken is dat het klassieke tweepartijenmodel in de huidige samenleving tekortschiet. Denk bijvoorbeeld aan de afwikkeling van massaschade: het voeren van talrijke (vergelijkbare) procedures tot vergoeding van de schade die door iedere gelaedeerde afzonderlijk is geleden, is inefficiënt en vergt te veel van het rechterlijk apparaat (denk aan de aandelenlease-zaken). Bauw wijst ook op de opkomst van de Public Interest Litigation (PIL), waarbij een belangenorganisatie een civiele procedure aanspant met het oog op de behartiging van collectieve en algemene belangen. Via de rechter wordt dan naar inspraak gezocht, omdat die inspraak langs politieke weg niet - of onvoldoende - kan worden bereikt. De klassieke civiele procedure biedt onvoldoende gelegenheid om de belanghebbenden in zulke gevallen een 'podium' te geven. Overigens komt de rechter als gevolg van PIL in 'politiek vaarwater' terecht: hij dient zich (daardoor) op zijn positie in de trias politica te beraden (regelgeving noch bestuur behoort immers tot zijn takenpakket). Bauw noemt als voorbeeld de - eerder bij de NVvP besproken - Urgenda-zaak. ${ }^{14}$

In procedures die over een 'zaakoverstijgend' belang gaan, moet de rechter rekening (kunnen) houden met de belangen van derden die niet als partij bij de procedure zijn betrokken. In verband met de toegenomen behoefte aan inspraak van derden in het (civiele) geding heeft het burgerlijk procesrecht in de afgelopen decennia al de nodige wijzigingen ondergaan. Bauw wijst op de volgende wijzigingen:

- De Hoge Raad heeft in 1986 aanvaard dat een vereniging of stichting in rechte kan opkomen voor het algemeen belang (een bundeling van krachten maakt een

14. Zie voor de Urgenda-zaak o.m. Rb. Den Haag 24 juni 2015 ECLI:NL:RBDHA:2015:7145 en Hof Den Haag 9 oktober 2018, ECLI:NL:GHDHA:2018:2591. Mr. J.M. van den Berg heeft deze zaak ook besproken tijdens de voorjaarsvergadering van 2016 van de NVvP. Zie hiervoor J.J. Dammingh \& L.M. van den Berg, 'Rechtspraak en politiek: hoe leven die samen in het ene huis, dat democratische rechtsstaat heet? Verslag van de voorjaarsvergadering 2016 van de Nederlandse Vereniging voor Procesrecht', TCR 2016, afl. 3, p. 113-116. 
efficiënte rechtsbescherming tegen de aantasting van een collectief en algemeen belang mogelijk). ${ }^{15}$

- De introductie - in 1994 - van art. 3:305a BW.

- De invoering - in 2005 - van de Wet collectieve afwikkeling massaschade (Wcam).

- De introductie - in 2012 - van de mogelijkheid om prejudiciële vragen aan de Hoge Raad te stellen (art. 392-394 Rv).

- De indiening - in 2016 - van wetsvoorstel 34608, strekkend tot de afwikkeling van massaschade in een collectieve actie. ${ }^{16}$

Bauw gaat nader in op art. 3:305a BW, dat het voor een stichting of vereniging - als belangenorganisatie - mogelijk maakt om een rechtsvordering in te stellen die strekt tot bescherming van gelijksoortige belangen van andere personen (de 'belanghebbenden'). Met zo'n collectieve actie worden de belangen van de belanghebbenden gebundeld (hoewel de procedure overigens volgens het klassieke model verloopt). Vanuit het perspectief van inspraak/invloed van de belanghebbenden zijn de volgende vragen relevant:

a. Welke invloed kunnen de belanghebbenden uitoefenen op de procesvoering door de belangenorganisatie?

b. Wat is de werking van de rechterlijke uitspraak in een collectieve actie ten opzichte van de belanghebbenden?

\section{Ad a. Invloed belanghebbenden op procesvoering}

De thans in art. 3:305a lid $2 \mathrm{BW}$ vervatte ontvankelijkheidseisen garanderen niet dat de belanghebbenden (voldoende) inspraak in de belangenorganisatie hebben. Voor een vereniging geldt dat de leden zeggenschap hebben. Bij een stichting is zeggenschap van de belanghebbenden - als 'deelnemers' echter niet gegarandeerd (ook niet in de 'governance-eisen' in de Claimcode).

In het thans aanhangige wetsvoorstel 34608 worden de ontvankelijkheidseisen (voor stichtingen) aangescherpt: de '305a-organisatie' moet onder meer beschikken over 'passende en doeltreffende mechanismen' voor de deelname aan of vertegenwoordiging bij de besluitvorming van de belanghebbenden.

\section{Ad b. Werking rechterlijke uitspraak voor belanghebbenden}

In art. 3:305a BW is bepaald dat een rechterlijke uitspraak geen gevolg heeft ten aanzien van een belanghebbende die zich tegen de werking van de uitspraak ten opzichte van hem verzet. De Wcam gaat uit van gebondenheid aan de uitspraak voor alle belanghebbenden die geen gebruik van de 'opt out'mogelijkheid maken. Hetzelfde geldt voor wetsvoorstel 34608 .

15. HR 17 juni 1986, NJ 1987/743 (Nieuwe Meer) en HR 18 december 1992, NJ 1994/139 (Kuunders).

16. Vgl. de inleiding van mr. J.H. Lemstra tijdens de najaarsvergadering van 2016 van de NVvP. Zie hiervoor J.J. Dammingh \& L.M. van den Berg, 'Procesfinanciering door derden: een oplossing of een probleem? Verslag van de najaarsvergadering 2016 van de Nederlandse Vereniging voor Procesrecht', TCR 2017, afl. 2, p. 80-82.

\section{Ad 2. De mogelijkheden voor de rechter om door derden te worden geïnformeerd}

In het klassieke procesmodel zijn er slechts in zeer beperkte mate mogelijkheden voor de rechter om zich door derden te laten informeren over de gevolgen van een door hem te nemen beslissing. Dit terwijl in een complexe samenleving als de huidige de rechtsvormende taak van de rechter meer gewicht heeft gekregen (en de impact van een rechterlijke beslissing dus groter zal zijn).

In het rapport Versterking van de cassatierechtspraak van de Commissie normstellende rol Hoge Raad uit 2008 (hierna: Commissie Hammerstein $)^{17}$ is aandacht besteed aan - een versterking van - de rechtsvormende rol van de Hoge Raad. Nadien is onder meer art. 80a van de Wet op de rechterlijke organisatie (Wet RO) geïntroduceerd, dat de Hoge Raad meer ruimte biedt om zich te concentreren op de zaken die er 'echt toe doen'. De invoering van de regeling van de prejudiciële vragen aan de Hoge Raad (vervat in art. 392-394 Rv) heeft eveneens bijgedragen aan een versterking van de rechtsvormende taak van de Hoge Raad.

Echter, die versterkte rechtsvormende taak makt het volgens Bauw wel wenselijk dat de mogelijkheden tot inspraak van derden worden verruimd. Dit is ook onderkend in voormeld rapport van de Commissie Hammerstein uit 2008. Art. 393 lid 2 Rv geeft de Hoge Raad de mogelijkheid om - in het kader van een aan hem voorgelegde prejudiciële vraag - aan anderen dan partijen inlichtingen te vragen. ${ }^{18}$ Dit (mede) omdat een door de Hoge Raad te geven beslissing niet alleen voor de partijen in de betreffende procedure, maar ook voor anderen (in de samenleving) van betekenis kan zijn. In art. 8 van het 'Reglement prejudiciële vragen van de civiele kamer van de Hoge Raad der Nederlanden'19 is het verstrekken van inlichtingen door derden op de voet van art. 393 lid $2 \mathrm{Rv}$ nader uitgewerkt. Partijen mogen zich over de van derden ontvangen inlichtingen uitlaten, maar die inlichtingen worden niet openbaar gemaakt. Bauw refereert in dit verband ook aan een door UCALL ${ }^{20}$ in 2016 uitgebracht onderzoeksrapport. ${ }^{21}$ Hierin is mede aandacht besteed aan de wijze waarop de Hoge Raad met art. 393 lid 2 Rv omgaat. De conclusie van de onderzoekers is dat de Hoge Raad een (veel) te passieve houding aanneemt. Zo worden derden te weinig benaderd, en als er (wel) inlichtingen door derden zijn verstrekt, blijkt (uit de uitspraak) onvoldoende wat de Hoge Raad met die inlichtingen heeft gedaan. Er is kortom nog een wereld te winnen als het gaat om het gebruik - door de Hoge Raad - van de mogelijkheid die art. 393 lid 2 Rv biedt, aldus Bauw.

Bauw pleit krachtig voor een verruiming van de mogelijkheden voor de rechter om met het oog op een door hem te geven beslissing inlichtingen bij derden in te winnen. Zo zou

17. Dit rapport is onder meer te vinden op de website www.recht.nl.

18. Deze mogelijkheid is er ook in zaken waarin cassatie in het belang der wet is ingesteld. Zie o.m. HR 6 juni 2014, ECLI:NL:HR:2014:1342.

19. Dit reglement is te vinden op www.rechtspraak.nl.

20. Utrecht Centre for Accountability and Liability Law.

21. E. Bauw e.a., Rechtsvergelijkend onderzoek naar de vergoeding van schade als gevolg van (voormalige) steenkoolwinning in Nederland, België en Duitsland, Den Haag: Boom juridisch 2016. 
de bevoegdheid die in art. 393 lid $2 \mathrm{Rv}$ aan de Hoge Raad is toegekend ook in andere zaken aan de Hoge Raad moeten toekomen. En de Hoge Raad zou dan (veel) actiever moeten zijn, door vaker derden uit te nodigen en duidelijker in zijn uitspraak te laten blijken welke invloed de ontvangen inlichtingen op de uitspraak hebben gehad. Tevens ligt het volgens Bauw voor de hand dat de ontvangen inlichtingen openbaar worden gemakkt, en ook zouden geraadpleegde derden op de zitting moeten (kunnen) worden gehoord.

\section{Ad 3. Inspraak (van derden) in de organisatie van de rechtspraak}

Bauw gaat tot slot nog kort in op de inspraak van derden ten aanzien van de organisatie van de rechtspraak. Er zijn concrete stappen genomen om die inspraak te vergroten. Zo kennen de gerechten tegenwoordig een maatschappelijke adviesraad. Ook worden er klantwaarderingsonderzoeken uitgevoerd. Verder is het inmiddels gebruikelijk dat met het oog op het maken van een nieuw procesreglement relevante organisaties worden geconsulteerd. In common law-stelsels wordt wel met 'user groups' gewerkt. Bauw wijst bijvoorbeeld op de User Committees van het Commercial Court in Londen. Deze dragen mede verantwoordelijkheid voor het bevorderen van een eerlijk, efficiënt en effectief proces. Wellicht iets voor het Nederlandse Commercial Court, zo oppert Bauw.

\section{Discussie}

De Groot (raadsheer in de Hoge Raad) maakt een aanvullende opmerking over het al dan niet openbaar maken van inlichtingen die op de voet van art. 393 lid $2 \mathrm{Rv}$ door derden (aan de Hoge Raad) zijn verstrekt. De A-G kan in zijn conclusie wel melding maken van de inhoud van ontvangen inlichtingen, maar art. 29 lid 2 Rv verhindert dat de Hoge Raad de van derden ontvangen inlichtingen openbaar maakt (c.q. publiceert), aldus De Groot. Dat is dus anders dan bij bestuursrechtelijke zaken. Overigens worden in fiscale zaken de inlichtingen van derden (via internet) gepubliceerd.

Bauw vraagt zich af wat te prefereren is: geen of beperkte openbaarheid (zoals in civiele zaken) of volledige openbaarheid (zoals in fiscale zaken)? Wat De Groot betreft dient er - in civiele zaken - steeds een belangenafweging plaats te vinden ter zake van gegevens die partijen niet geopenbaard willen zien. Het belang van partijen (bij niet-openbaarmaking) dient dan te worden afgewogen tegen het belang (van de rechtsstaat) bij openbaarmaking.

Knigge (advocaat) merkt op dat uit de inleiding van Bauw valt af te leiden dat de rechter niet langer alleen maar een klassieke 'geschilbeslechter' is, maar met zijn beslissingen ook invloed heeft op het politieke en bestuurlijke proces. Schuilt daarin niet het gevaar dat de rechter onderdeel van de politiek wordt, en aldus mogelijk gedwongen wordt om politiek 'kleur' te bekennen?

Bauw onderschrijft dat die discussie kan ontstaan, en voor hem is niet op voorhand evident hoe daarmee moet worden omgegaan. Aan de ene kant is er de scheiding van machten binnen de trias politica, maar daar staat tegenover dat elk van die machten opkomt voor dezelfde rechtsstaat. Als de politiek c.q. het bestuur een leemte laat ontstaan door (ten onrechte) regelgeving achterwege te laten, dan lijkt het Bauw niet onwenselijk dat die leemte door de rechter wordt opgevuld. Zie bijvoorbeeld de Urgenda-zaak. Overigens is het natuurlijk wel de vraag waar de grens ligt.

Langemeijer (plv. P-G bij de Hoge Raad) merkt op dat zeer recent een nieuw procesreglement bij het Benelux Gerechtshof van kracht is geworden met daarin een aparte bepaling over de inschakeling van een amicus curiae. Hij denkt dat het inzetten van een amicus curiae nuttig kan zijn in bestuursrechtelijke zaken (over bijvoorbeeld een bestemmingsplan). Langemeijer vraagt zich wel af hoe - in civiele zaken - om te gaan met de figuur van de amicus curiae wanneer bepaalde actiegroepen nadrukkelijk hun stem laten horen, terwijl niet of nauwelijks tegenwicht door andere amici wordt geboden.

Bauw erkent het probleem: de ene hoek laat wel van zich horen, maar de andere niet. In een dergelijk geval is er wat hem betreft weinig op tegen om ook één of meer amici gericht uit te nodigen.

\section{Inleiding prof. dr. J.S. Kortmann ${ }^{22}$}

Stellingen:

1. Het instrument van de oproeping in vrijwaring (art. 210 e.v. Rv) functioneert, met name in gevallen van (gestelde) hoofdelijkheid, niet goed.

2. De lagere rechtspraak is - veelal op onjuiste gronden terughoudend met de toepassing van het instrument van de 'gedwongen voeging of tussenkomst' van art. 118 Rv.

3. De rechtspraktijk heeft behoefte aan een procesrechtelijk instrument waarmee kan worden bewerkstelligd dat het gezag van gewijsde zich uitstrekt tot een derde, zonder dat die derde noodzakelijkerwijs partij wordt bij de procedure (vergelijk het Duitse instrument van de Streitverkündung).

\section{Inleiding}

Kortmann bespreekt de rol van derden bij hoofdelijke aansprakelijkheid. Daarbij heeft hij het geval voor ogen waarin de beweerdelijk gelaedeerde één of meer hoofdelijk aansprakelijke partijen in rechte betrekt, maar één of meer andere eveneens hoofdelijk verbonden schuldenaren buiten schot laat. In een dergelijk geval zullen doorgaans de schuldenaren die niet in de procedure zijn betrokken door de gedaagden in vrijwaring worden opgeroepen. Er volgt dan een gelijktijdig oordeel waarin ook wordt uitgemaakt wat ieder van de hoofdelijk verbonden schuldenaren in de schadevergoeding moet bijdragen. De vrijwaringsprocedure heeft in deze vorm volgens Kortmann de volgende belangrijke nadelen.

22. Hoogleraar Europees aansprakelijkheidsrecht aan de Universiteit van Amsterdam en advocaat te Amsterdam. 
Vaststellingen in de hoofdprocedure binden de partijen in vrijwaring niet. Dit plaatst de gedaagde in de hoofdzaak in een ingewikkelde spagaat. Deze partij is voor de relevante feiten afhankelijk van wat de overige schuldenaren weten. Maar er is ook het gezamenlijke belang van de schuldenaren dat de vordering in de hoofdzaak wordt afgewezen of verminderd. De gedaagde in de hoofdzaak zal zich daarom in de regel wenden tot de gedaagde in vrijwaring voor hulp. Deze onderkent wel het belang van samenwerken, maar ziet zich ook geconfronteerd met de procedure in vrijwaring waarin de partijen elkaars tegenstanders zijn. In ruil voor steun in de hoofdzaak wordt dan vaak verlangd dat de vrijwaringsprocedure wordt aangehouden. Zodra een dergelijke afspraak wordt gemaakt, laat de steun aan de gedaagde in de hoofdzaak echter te wensen over omdat de gedaagde in vrijwaring niet meer de druk van de vrijwaringsprocedure voelt. De gedaagde in vrijwaring realiseert zich namelijk dat in een eventueel hervatte vrijwaringsprocedure de feiten opnieuw zullen worden vastgesteld. Een omissie laat zich in die procedure herstellen. De hulp aan de gedaagde in de hoofdzaak is daarom vrijblijvend. Er is niet een echte impuls om bij te dragen aan een juiste vaststelling van de feiten in de hoofdzaak.

Aldus ontstaat ook het risico dat de rechter in de hoofdzaak de feiten onjuist of onvolledig vaststelt. In de vrijwaringsprocedure, of een afzonderlijke procedure tegen andere hoofdelijk verbonden schuldenaren, kunnen alsnog de juiste, volledige feiten op tafel komen, die in de hoofdzaak mogelijk tot een ander oordeel over de aansprakelijkheid zouden hebben geleid.

Een verschil in feitelijke grondslag tussen hoofdzaak en vrijwaring kan ook van invloed zijn op de onderlinge draagplicht van de hoofdelijk verbonden schuldenaren. Bij het bepalen van de onderlinge draagplicht is immers sprake van communicerende vaten: een vermindering van de bijdrage van een van de schuldenaren betekent een vermeerdering van de bijdrage van de overige schuldenaren. Daar komt bij dat in geval van faillissement van een van de schuldenaren op de voet van art. 6:13 BW de onverhaalbare bijdrage van deze schuldenaar wordt omgeslagen over de overige schuldenaren. Dit blijkt vaak pas als de vonnissen al zijn gewezen.

Voormelde bezwaren zijn bekend. Ze stonden al in de eerste druk van het mooie proefschrift van W.H. van Boom. ${ }^{23}$ Internationaal bestaat consensus erover dat in het ideale geval alle hoofdelijk verbonden schuldenaren in de hoofdzaak betrokken worden. Van Boom ${ }^{24}$ betoogt dat dit kan worden gerealiseerd door op basis van art. $118 \mathrm{Rv} / 30 \mathrm{~g} \mathrm{Rv}$ (nieuw) in gevallen van hoofdelijke aansprakelijkheid de nog niet in de procedure betrokken schuldenaren desverlangd of zelfs ambtshalve op te roepen. A.C. van Schaick wijst erop dat ingevolge $\$ 72$ Zivilprozessordnung (ZPO) de partij die een veroordeling vreest, de derde op wie zij alsdan verhaal meent te hebben, formeel op

23. W.H. van Boom, Hoofdelijke verbintenissen (diss. Tilburg), Deventer: W.E.J. Tjeenk Willink 1999.

24. W.H. van Boom, Hoofdelijke verbintenissen, Den Haag: Boom juridisch 2016. de hoogte kan stellen van de lopende procedure, de zogeheten Streitverkündung. ${ }^{25}$

Kortmann staat eerst stil bij art. $118 \mathrm{Rv}$, waarin het volgende is bepaald:

'Oproepingen van derden als partij in het geding geschieden met inachtneming van de termijnen die gelden voor de betekening van de procesinleiding bij de belanghebbende of verweerder. Indien de oproeping niet geschiedt bij dezelfde procesinleiding waarmee de belanghebbende of verweerder in de procedure is betrokken, wordt de procesinleiding, waarmee de belanghebbende of verweerder in de procedure is betrokken, met de oproeping bij de derde betekend.'

Naar de letter is dit alleen een procedureel voorschrift ter zake van de oproeping van derden. In de rechtspraak wordt deze bepaling echter zo geïnterpreteerd dat zij ook een grondslag voor de oproeping van derden biedt. Volgens de Hoge Raad is art. $118 \mathrm{Rv}$ 'bedoeld voor gevallen waarin het voor de beslissing over de rechtsbetrekking in geschil noodzakelijk is of zinvol is om de derde als partij in het geding te betrekken'. ${ }^{26}$ Voor een recent geval waarin de oproeping noodzakelijk was, verwijst Kortmann naar HR 20 april 2018, NJ 2018/214 (ECLI:NL:HR:2018:649). Daar betrof het de verdeling van een nalatenschap. Ook dan is sprake van communicerende vaten. Wat aan de een wordt toebedeeld, moet de ander missen.

Kortmann illustreert aan de hand van de volgende kartelschadezaak uit zijn praktijk welk belang de toepassing van art. $118 \mathrm{Rv}$ kan hebben. Eiseres heeft een vordering ingesteld tegen twee van de vier hoofdelijk verbonden schuldenaren. Tegen de andere twee schuldenaren zijn vrijwaringsprocedures geopend. De hoofdzaak tegen een van de gedaagden wordt geschikt. Deze heeft bedongen dat eiseres de hoofdzaak tegen de andere gedaagde zal voortzetten op basis van de volledige oorspronkelijke eis, echter te verminderen met de door de rechter te bepalen bijdrage van de gewezen gedaagde in de schade. Kortmann heeft in dit geval namens de overgebleven gedaagde bepleit dat het noodzakelijk, althans zinvol is om ook de gewezen gedaagde en de gedaagden in vrijwaring in de hoofdzaak op te roepen, met het argument dat de bijdrage van de overgebleven gedaagde in de hoofdzaak anders niet goed vastgesteld kan worden. In een dergelijk geval heeft de rechter doorgaans wel oog voor de hiervoor bedoelde problematiek. Vervolgens wordt echter geoordeeld dat de oproeping niet noodzakelijk is. Dat is volgens Kortmann op zichzelf juist, nu strikt genomen van een ondeelbare rechtsverhouding geen sprake is. De zaak draait alleen om geld. Wellicht dat de bijdrage van de een wat te hoog en die van de ander wat te laag

25. A.C. van Schaick, Mr. C. Assers Handleiding tot de beoefening van het Nederlands burgerlijk recht. Procesrecht. 2. Eerste aanleg, Deventer: Wolters Kluwer 2016, nr. 37.

26. HR 28 maart 2014, ECLI:NL:HR:2014:736, NJ 2014/525, m.nt. P.C.E. van Wijmen en W.D.H. Asser, overweging 3.14. 
wordt vastgesteld, maar dat leidt niet tot een echt executieprobleem, zoals wel voorzienbaar was in de hiervoor aangehaalde zaak waarin de Hoge Raad op 20 april 2018 uitspraak deed. Dat oproeping in een dergelijk geval zinvol is, acht Kortmann echter evident. Het is anders niet goed mogelijk om de bijdrage van de overgebleven schuldenaar in de hoofdzaak te bepalen. Toch wijst de rechter de oproeping in een dergelijk geval vaak af, bijvoorbeeld met de volgende motivering: 'De rechtbank deelt niet de opvatting van gedaagden dat het aandeel van $[\mathrm{A}]$ niet kan worden vastgesteld zonder dat [C, D ...] deelnemen aan de partijdiscussie daarover. ${ }^{27}$

Kortmann onderschrijft dit oordeel niet, maar begrijpt het wel. Met een hoofdzaak tegen meerdere gedaagden en verschillende vrijwaringsprocedures is de zaak al gecompliceerd genoeg. Het wordt dan nog ingewikkelder als de gedaagden in vrijwaring en de gewezen gedaagde in de hoofdzaak ook allemaal (opnieuw) in de hoofdzaak zouden gaan figureren. De rechtbank zal begrijpelijkerwijs denken: zo blijven we aan de gang. De vraag is vervolgens of het probleem van de overgebleven gedaagde in de hoofdzaak alleen met toepassing van art. 118 Rv kan worden opgelost.

$\$ 72(1) Z$ ZPO, waarnaar Van Schaick verwijst, is afgeleid van de litis denuntiatio uit het Romeinse recht en luidt als volgt:

'Eine Partei, die für den Fall des ihr ungünstigen Ausganges des Rechtsstreits einen Anspruch auf Gewährleistung oder Schadloshaltung gegen einen Dritten erheben zu können glaubt oder den Anspruch eines Dritten besorgt, kann bis zur rechtskräftigen Entscheidung des Rechtsstreits dem Dritten gerichtlich den Streit verkünden.'

De kern van deze bepaling is dat in een procedure tussen eiser en gedaagde, waarin de gedaagde vindt dat de vaststellingen die gaan plaatsvinden rechtstreeks raken aan de belangen van een andere partij, deze gedaagde met toestemming van de rechter informatie aangaande het geding kan laten betekenen aan die andere partij. $\mathrm{Na}$ deze kennisgeving heeft de aangeschreven partij de keuze om al dan niet (na verloop van tijd) in de procedure te verschijnen. Deze keuze is niet vrijblijvend, in die zin dat deze partij achteraf niet met vrucht kan opwerpen dat de feiten niet goed zijn vastgesteld. $\mathrm{Zij}$ heeft immers gelegenheid gehad om in de hoofdzaak te verschijnen en de feitenvaststelling te beïnvloeden. Zie daarvoor $\$ 74(3)$ jo. $\$ 68 \mathrm{ZPO}$. De figuur van de Streitverkündung ligt tussen de vrijwaring en het zware middel van art. $118 \mathrm{Rv}$ in en zou een oplossing kunnen bieden voor de problemen die Kortmann aan het begin van zijn inleiding heeft geschetst. Ze zet niet in de hoofdzaak betrokken hoofdelijk verbonden schuldenaren aan tot een actieve bijdrage aan de vaststelling van feiten. Het risico op een gebrekkige feitelijke grondslag wordt door de hoofdelijk verbonden schuldenaren gezamenlijk gedragen. Dit draagt volgens Kortmann bij aan juiste beslissingen.

27. Rb. Den Haag 21 september 2016, ECLI:NL:RBDHA:2016:11305.

\section{Discussie}

Möhlmann ( advocaat $^{28}$ ) vraagt zich af of Kortmann heeft willen betogen dat het zware middel van art. $118 \mathrm{Rv}$ voor de door hem geschetste problemen eigenlijk geen soelaas biedt en in plaats daarvan de Streitverkündung zou moeten worden gehanteerd.

Volgens Kortmann is de rechter te terughoudend bij de toepassing van art. $118 \mathrm{Rv}$ en heeft hij te weinig oog voor de problematische positie van de gedaagde in de hoofdzaak. Toepassing van art. $118 \mathrm{Rv}$ leidt weliswaar tot een ingewikkelder hoofdzaak, maar beziet men de procedure als geheel, dus met inbegrip van de verschillende vrijwaringsprocedures, dan is per saldo juist sprake van een vereenvoudiging, omdat de feiten maar één keer hoeven te worden vastgesteld. De verwachting van de rechter dat de vrijwaringsprocedures na afloop van de hoofdzaak wel zullen worden geschikt, is waarschijnlijk juist, maar de gedaagde in de hoofdzaak delft in de onderhandelingen niet zelden het onderspit, in die zin dat deze meer in de schadevergoeding bijdraagt dan waartoe hij rechtens is verplicht. De Streitverkündung zou een mooi alternatief kunnen zijn voor de toepassing van art. $118 \mathrm{Rv}$.

Kortmann signaleert volgens Möhlmann het dilemma dat de in de hoofdzaak gedaagde hoofdelijke schuldenaar medewerking van andere hoofdelijke schuldenaren moeilijk kan afdwingen, terwijl deze aan feitelijke vaststellingen in de hoofdzaak niet zijn gebonden. De eisende partij die tegen een hoofdelijk verbonden schuldenaar procedeert, hoeft zich echter niets aan te trekken van dit dilemma in de regresverhouding. Möhlmann vraagt zich af wat, tegen deze achtergrond, de rechtvaardiging is om de eiser via de toepassing van art. 118 $\mathrm{Rv}$ te belasten met een veel complexere, langduriger en duurdere procedure.

De veronderstelling dat alleen sprake is van regresproblematiek is volgens Kortmann niet juist. Het gaat ook erom dat informatie over de relevante feiten deels slechts bekend is bij de andere hoofdelijk verbonden schuldenaren. De figuur van de hoofdelijkheid stelt de eiser in staat het risico van onvindbaarheid of insolventie van een schuldenaar te ontlopen. Deze figuur biedt de eiser echter niet de mogelijkheid om te ontkomen aan feitelijke verweren waarvan alleen de niet in de hoofdzaak betrokken hoofdelijk verbonden schuldenaren weet hebben. Hierin ligt de rechtvaardiging voor de toepassing van art. $118 \mathrm{Rv}$. Die rechtvaardiging wordt daardoor ondersteund, dat de gedaagde in vrijwaring zichzelf wel mag melden in de hoofdzaak. Daar kan de eiser in de hoofdzaak zich niet tegen verzetten.

Volgens Bongaerts (advocaat) verkrijgt de uitspraak in een procedure waarin een collectieve belangenbehartiger de eiser is, geen gezag van gewijsde tussen de gedaagde schuldenaar en de uiteindelijk gedupeerden. Er is dan geen mogelijkheid de in die uitspraak vastgestelde verplichting tot schadevergoeding af te wentelen op niet in de hoofdzaak betrokken hoofdelijk verbonden schuldenaren. Met andere woorden, er is geen af te

28. Tevens auteur van het hiervoor in voetnoot 2 genoemde artikel in TCR 2017, afl. 3 . 
wentelen veroordeling in een collectieve actie. Is in een dergelijke procedure wel plaats voor een vrijwaringsprocedure, zo vraagt Bongaerts zich af.

Kortmann werpt op dat in de grote massaschadezaken geen gebruik is gemakkt van art. 3:305a BW. De eisers in die zaken hadden via volmacht of cessie de controle over een bundel aan vorderingen. Kortmann denkt dat het mogelijk juist is dat bij een 305a-procedure geen plaats is voor de figuur van vrijwaring. Maar juist dan is er volgens hem voor de toepassing van art. $118 \mathrm{Rv}$ veel te zeggen.

Volgens Knigge bestaat een evident belang bij de vrijwaring als in de 305a-procedure de vaststelling van aansprakelijkheid voor schade is gevorderd.

Hermans werpt op dat onder KEI de verzoek- en de vorderingsprocedure gedeeltelijk zijn geüniformeerd. Hij vraagt zich af of het grootste obstakel voor volledige harmonisatie van de baan is indien de vrijwaringsprocedure wordt afgeschaft en de mogelijkheid voor gedwongen voeging wordt verruimd.

Kortmann begrijpt art. $118 \mathrm{Rv}$ aldus dat de opgeroepen partijen weliswaar zijn gebonden aan de vaststellingen in de hoofdzaak, maar dat tegen deze partijen in de hoofdzaak geen vordering kan worden gericht. Het afschaffen van de vrijwaring kan er dus toe leiden dat de gedaagde in de hoofdzaak na afloop van de procedure geen titel voor regres heeft en de schadevergoeding moet voorfinancieren, in afwachting van de afloop van afzonderlijke procedures tegen hoofdelijk verbonden medeschuldenaren, en aldus een insolventierisico gaat lopen. Dit probleem zal in ieder geval moeten worden ondervangen als de vrijwaring zou worden afgeschaft.

Hermans kan zich voorstellen dat na oproeping van een derde in de hoofdzaak de eiser ook een eis tegen deze derde mag instellen. Als de eiser daartoe niet overgaat, zou de oorspronkelijke gedaagde alleen voor zijn bijdrage aan de schade aangesproken kunnen worden.

Kortmann merkt op dat dit zou neerkomen op een beperking van het recht van de schuldeiser om de vordering slechts tegen een hoofdelijk verbonden partij in te stellen. Dat lijkt hem te ver te gaan.

Volgens Möhlmann zou met het systeem dat Hermans voor ogen heeft een hele waaier aan potentieel hoofdelijk aansprakelijke partijen in de hoofdzaak betrokken kunnen worden, zoals bijvoorbeeld een toezichthouder, terwijl de eiser daarbij helemaal geen belang heeft. Door gedwongen voeging op deze wijze toe te staan zou een einde komen aan de hoofdelijkheid, aldus Möhlmann.

Volgens Tzankova (hoogleraar en advocaat) is een spraakverwarring ontstaan over het begrip amicus curiae. Het is in haar beleving een onafhankelijke partij met een bijzondere deskundigheid die gericht kan worden benaderd; het gaat niet om een partij met een eigen belang, zoals lobbyorganisaties. Zij deelt verder de volgende observatie met de zaal. In de Fortis-zaak ${ }^{29}$ heeft het Gerechtshof Amsterdam het publiek opgeroepen om zienswijzen in te dienen over de financieringsstructuren van belangenorganisaties. Anders dan in het bestuursrecht zijn die niet ingebracht. Hoe kan dit verschil worden verklaard?

De Poorter licht toe dat de amicus in de bestuursrechtspraak geen onafhankelijke deskundige is. De rechter heeft juist maatschappelijk betrokken partijen op het oog, die bij de uitkomst van de procedure belang hebben en dus een gekleurde reactie zullen indienen. Bepleit wordt dat de amicus ook ertoe zou moeten strekken rechtsbescherming te bieden, bijvoorbeeld in het geval dat een principiële zaak moet worden beslist, in afwachting waarvan andere zaken waarin dezelfde vraag speelt, zijn aangehouden. Hier acht De Poorter terughoudendheid op haar plaats.

Bauw spreekt liever van de inbrenger van schriftelijke opmerkingen. Van de mogelijkheid om in te spreken bij prejudiciële vragen aan de Hoge Raad maken voornamelijk belangenorganisaties als de Koninklijke Beroepsorganisatie van Gerechtsdeurwaarders en de Vereniging van Banken gebruik. Anders dan in de Verenigde Staten gebruikelijk is, hebben universiteiten of maatschappelijke organisaties nog niet gereageerd. Het lijkt Bauw daarom voorbarig in Nederland al te spreken van een amicus curiae.

Volgens Kortmann is de benaming verkeerd omdat het iets suggereert wat het niet is. Een belangenorganisatie zoals bijvoorbeeld de Consumentenbond kwalificeren als een amicus curiae wekt de verkeerde indruk. De neutrale term 'derde' is beter, aldus Kortmann.

De Poorter merkt op dat in de eerste zaak waarin de $\mathrm{ABRvS}$ het instrument heeft ingezet, van zogenoemde 'meedenkers' inspraak is gevraagd. Dat is wellicht een betere term.

Uit de Fortis-zaak, waarin zonder wettelijke grondslag inspraak is gevraagd, blijkt een behoefte van rechters aan inspraak van derden, aldus Bauw. Dit pleit voor een wettelijke regeling.

Kortmann wijst erop dat in de Fortis-zaak de eigenaardigheden van de Wcam meespeelden. Dat is in die zin een bijzondere procedure dat de partijen hetzelfde willen, namelijk verbindendverklaring van een regeling. Eventuele bedenkingen daartegen zullen zij wegwuiven. Als de rechter voelt dat er serieuze bezwaren denkbaar zijn, dan kan er behoefte zijn aan het organiseren van inspraak. Er zullen overigens ongetwijfeld partijen hebben willen inspreken die daarvan uiteindelijk hebben afgezien omdat die inspraak niet in het belang van hun client zou zijn.

Volgens Tzankova is juist in een Wcam-zaak de inspraak van professional objectors van belang.

Dan ontstaat volgens Kortmann wel het al gesignaleerde risico van inequality of arms, omdat de belangen van de ene zijde wel, maar van de andere zijde niet worden belicht. 
De voorzitter dankt de sprekers en kondigt aan dat de volgende vergadering, over de Experimentenwet rechtspleging, ${ }^{30}$ in beginsel zal plaatsvinden op 23 november 2018.

30. Zie www.internetconsultatie.nl/experimenten. 